Bryn Mawr College

Scholarship, Research, and Creative Work at Bryn Mawr College

1996

\title{
"Capital Spectacles in British Frames": Capital, Empire and Indian Indentured Migration to the British Caribbean
}

Madhavi Kale

Bryn Mawr College, mkale@brynmawr.edu

Let us know how access to this document benefits you.

Follow this and additional works at: http://repository.brynmawr.edu/history_pubs

Part of the History Commons

\section{Custom Citation}

Kale, Madhavi. "'Capital Spectacles in British Frames': Capital, Empire and Indian Indentured Migration to the British Caribbean." International Review of Social History 41 (1996): 109-133.

This paper is posted at Scholarship, Research, and Creative Work at Bryn Mawr College. http://repository.brynmawr.edu/history_pubs/8

For more information, please contact repository@brynmawr.edu. 


\title{
"Capital Spectacles in British Frames": Capital, Empire and Indian Indentured Migration to the British Caribbean*
}

\author{
MADHAVI KALE
}

They came in ships.

From across the seas, they came.

Britain, colonising India, transporting her chains

from Chota Nagpur and the Ganges Plain.

Westwards came the Whitby,

The Hesperus,

The Island-bound Fatel Rozack.

Wooden missions of imperialist design.

Mahadai Das, "They Came in Ships"1

As "They Came in Ships" by the Guyanese poet Mahadai Das suggests, scholarship on indentured immigration is not an exclusively academic concern in Caribbean countries with sizeable Indian populations. An international conference on Indian diaspora held recently at the University of the West Indies, Trinidad and Tobago, was not only covered by national news media, but also attended by Trinidadians (almost exclusively of Indian descent) unattached to the university, some of whom also contributed papers, helped to organize and run it. ${ }^{2}$ In Guyana and Trinidad and Tobago, contestations over national identities are grounded in and self-consciously refer to a shared historical archive. This includes conventional, written material such as colonial administration records, newspapers, travelogues, and memoirs that reflect the concerns of privileged observers: government officials, reporters and editors, missionaries,

\footnotetext{
- Research for this project was supported by dissertation fellowships from the Mellon Foundation and Social Science Research Council-South Asia programme, and by a faculty research grant from Bryn Mawr College. Many thanks to Rob Gregg, Shahid Amin and Antoinette Burton for reading and commenting on earlier drafts of this article.

"Mahadai Das, "They Came in Ships", in David Dabydeen and Brinsley Samaroo (eds), India in the Caribbean (London, 1987), pp. 288-289.

2 ISER-NCIC Conference on Challenge and Change: The Indian Diaspora in its Historical and Contemporary Contexts, University of the West Indies, St Augustine, Trinidad and Tobago, 11-18 August 1995.
} 
labour activists, historians, anthropologists. It also includes memories and accounts of personal and group experiences by others in these societies, transmitted orally or through other popular media, and they all simultaneously and unevenly undermine as well as authorize each other. ${ }^{3}$

Two issues continue to frame debate on the history and politics of Indian immigration and cultural diversity in the English-speaking Caribbean. One, on which the first part of this article focuses, concerns interpretation of emancipation and its aftermath. Was Trinidad's sugar industry threatened by emancipation and "saved" by indentured immigration (from India, but also - on a smaller scale - from Sierra Leone, China and elsewhere)? Or did the introduction of indentured labourers from overseas undermine Afro-Trinidadian labourers' prospects in the post-emancipation period? The second, related set of questions articulates with the first and with emergent imperial discourses on race, class, gender and nation. In the context of post-emancipation Trinidad, this involved crystallization of a cultural register calibrated to the needs of an increasingly monopolistic sugar industry and an empire predicated on naturalizing and reproducing hierarchies of race, class, gender and nation along which ethnically-constituted populations in the colony were continuously, contradictorily evaluated. ${ }^{4}$ Were Indian indentured migrants the outcasts of colonial Indian society, "the sweepings of bazaars" as some contemporaries claimed? Or were they "respectable" folk - pushed out of traditional villages by deteriorating economic or (particularly in the case of women migrants) social conditions, and either trapped or drawn by often unscrupulous recruiters into taking the enormous risk of emigrating to improve their lives and prospects? Were they, like Afro-Trinidadian working people, also victims and unwilling instruments of British imperialism? Or were they cannily complicit in the reassertion of a racially-inflected plantation economy in the post-

\footnotetext{
${ }^{3}$ Rhoda Reddock, "Contestations over National Culture in Trinidad and Tobago: Considerations of Ethnicity, Class, Race and Gender", paper presented at Bryn Mawr/Haverford/ Swarthmore Colleges series on Colonialism and the Disciplines, 29 February 1996; D.V. Trotman, "The Image of Indians in Calypso: Trinidad 1946-86", in Frank Birbalsingh (ed), Indenture and Exile. The Indo-Caribbean Experience (Toronto, 1989), pp. 176-190; Jeremy Poynting, "East Indian Women in the Caribbean: Experience and Voice", in Dabydeen and Samaroo, India in the Caribbean, pp. 231-263; Monica Schuler, "Alas, Alas, Kongo": A Social History of Indentured African Immigration into Jamaica, I84I1865 (Baltimore, 1980); Shahid Amin, Event, Metaphor, Memory: Chauri Chaura, 19221992 (Berkeley, 1995).

${ }^{4}$ Madhavi Kale, "Projecting Identities: Empire and Indentured Labor Migration from India to Trinidad and British Guiana, 1836-1885", in Peter van der Veer (ed.), Nation and Migration: The Politics of Space in the South Asian Diaspora (Philadelphia, 1995), pp. 73-92; idem, "Casting Labor in the Imperial Mold", paper presented at Conference on Challenge and Change, University of the West Indies, St Augustine, Trinidad and Tobago, 13 August 1995.
} 
emancipation period? $?^{5}$ The second section of the article focuses on the literature on recruitment of indentured migrants in India: where, how and by whom migrants were recruited, the conditions prevailing at the time, and who was recruited.

In considering these two topics, this article questions the causal link established by contemporaries and further elaborated by historians and others between post-emancipation labour shortage on British Caribbean sugar plantations on the one hand, and patterns of labour recruitment in colonial India for those same plantations on the other. Indeed, I present these topics in an effort to uncouple these two narratives, and reconsider the imperial narrative train in which they have served as engine and caboose. Seventy-odd years of Indian indentured migration overseas, and more than a century and a half of struggle by migrants and their descendents both exceed the narratives that have been proposed to contain them. Indian indentured migration is not reducible to Caribbean (or Fijian, South African, and so on) "labour shortage", and formation of distinctive communities among migrants and their descendants is not reducible to tradition, great or little.

\section{Genesis}

Commissioners came, capital spectacles in British frames

consulting managers about costs of immigration.

Mahadai Das, "They Came In Ships"

Sugar planters in the British Caribbean had long complained that the labour available to them was inadequate, numerically or otherwise. After abolition of the slave trade, they explored the possibility of importing labourers from India and China to both augment and control the labour of slaves. ${ }^{6}$ The Act of Abolition, passed in 1833 by the reformed Parliament elected in 1832, reflected planters' and West India merchantcreditors' success in shielding their investments from hostile abolitionist sentiment. The Act provided that slave-owners be compensated for the loss of their human property through a combination of financial award (a sum of $£ 20$ million was approved for the purpose) and deferral of adult slaves' full emancipation for six years. It also provided that compensation be paid in London, rather than in the colonies, which

s See Aisha Khan, "Purity, Piety, and Power: Culture and Identity among Hindus and Muslims in Trinidad" (Ph.D., City University of New York, 1995), pp. 71-74.

${ }^{6}$ UK (HC) 1810-11, II, no. 409, "Report of the Select Committee Appointed to Consider the Practicability and Expediency of Supplying our West India Colonies with Free Labourers from the East"; B.W. Higman, "The Chinese in Trinidad, 1806-1838", Caribbean Studies, 12, 3 (1972), pp. 21-44. 
enabled merchant-creditors, who often held power-of-attorney for their clients, to recuperate some or all of the loans they had made to planters over the years. During this period former slaves were to continue to work as "apprentices" for their former masters for six days of the week in exchange for continued provision of customary allowances (food, clothing, housing). Apprenticeship was skipped entirely in some affected colonies, and ended early (summer 1838) elsewhere, subverted by the actions and interactions of both apprentices and planters.?

In December 1839, 773 "Clergy, Planters, Merchants, and other Inhabitants" of British Guiana signed a petition imploring the Queen and her ministers to give them the means to recuperate from a debilitating labour shortage precipitated by emancipation the previous year. Extolling the colony's enormous untapped natural resources and enormous economic potential, they warned that prevailing conditions were "not only pregnant with ruin to the landed interest of this colony, but prejudicial to the moral condition of the labourers themselves, as idleness tends to increase, and is almost universally the originator and companion of crime". They proposed that they be allowed to recruit plantation labourers from among "the vast population of India". Such a scheme would save investments already made in the colony's sugar industry, "open a field for the employment of a large additional amount of capital" in the colony's still-unexploited territories, "prevent the demoralization" of freedpeople, and finally, give undercompensated Indian labourers the opportunity to sell their labour "where the fertility of the soil, and demand for their labour, will ensure them comfortable, even abundant subsistence". 8

In a letter written to Colonial Secretary John Russell at the same time, the London West India Merchants' Association made the same case. They elaborated on the framework of labour shortage, British Guiana's potential for investment and profit, social crisis and imperial noblesse oblige. The Merchants' Association argued that estates in the colony were suffering from an absolute decline in the number of labourers available to them after emancipation, "many of the emancipated labourers having, since the 1st of August 1838, betaken themselves to petty trading, and other employments in preference to the cultivation of the soil, most of the women having altogether withdrawn, and the

7 Kathleen Mary Butler, The Economics of Emancipation: Jamaica and Barbados, 18231843 (Chapel Hill, 1995). UK (HC) 1836, no. 560, "Report of the Select Committee on Negro Apprenticeship in the Colonies"; UK (HL) 1839, VII, no. 1, Glenelg to Nicolay (Governor of Mauritius), 20 January 1836; W.K. Marshall, "The Termination of Apprenticeship in Barbados and the Windward Islands: An Essay in Colonial Administration and Politics", Journal of Caribbean History, II (May 1971), pp. 1-45; Hilary Beckles, Black Rebellion in Barbados: The Struggle against Slavery, 1627-1838 (Bridgetown, 1984).

${ }^{8}$ UK (HC) 1840, encl. in no. 23, Light to Russell, 23 December 1839, Petition to the Queen from British Guiana, 21 December 1839. 
children affording scarcely any assistance".9 They warned that wages currently being offered in the colony were so high that many good workers would "gradually become independent, purchase land, and cultivate provisions for their own account, and consequently withdraw themselves from the cultivation of exportable produce". The Merchants' Association complained that not only were emancipated men and women unreliable labourers, but they were also, in their capacity as parents, unreliable in reproducing labour. They lamented that, "unfortunately for themselves", emancipated youth were not being "trained up by their parents to industrious habits, and consequently, no assistance [could] be expected from them in the cultivation of produce at a future period" ${ }^{10}$

Like their counterparts in British Guiana, the Merchants' Association urged the government to allow interested employers in British Caribbean colonies to recruit workers from Africa and Asia, "those densely populated countries whose inhabitants, from climate and other circumstances, are best adapted for tropical labour". Such a scheme would be mutually beneficial to the Caribbean colonies and India, where "hundreds of thousands of the natives [ . . . ] were starved to death in 1838 , in various parts of that over-populated country, which is well known to be afflicted with a frightful dearth at times". They concluded:

it would, therefore, be an act of humanity, on the part of the British Government, to give the inhabitants of those regions access to a country capable of affording profitable employment to industrious labourers for ages to come, and where such dreadful calamities as that just adverted to are utterly unknown; a country where they would also have the means of obtaining religious instruction. ${ }^{11}$

Labour migration would address the shortage of labour in the British Caribbean, underemployment in India, and the not unrelated problems of immorality and heathenism at both ends of the empire.

For the most part, historians of emancipation and its aftermath have either modified this sugar and slavery line, or ignored it, focusing instead on the needs and logic of "plantation economy". ${ }^{12}$ However, research (sometimes that of these very historians) suggests that there was not as much consensus among colonial planters, freedpeople and officials or among metropolitan abolitionists, entrepreneurs and bureaucrats as the

${ }^{9}$ UK (HC) 1840, encl. 1, West India Association to Russell, 17 December 1839, in Russell to Light, 2 February 1840.

${ }^{10}$ lbid.

11 Ibid.

${ }^{12}$ See, for example, William A. Green, British Slave Emancipation: The Sugar Colonies and the Great Experiment 1830-1865 (New York, 1975); Eric Foner, Nothing But Freedom: Emancipation and its Legacy (Baton Rouge, 1983); Thomas Holt, The Problem of Freedom: Race, Labor, and Politics in Jamaica and Britain, 1832-1938 (Baltimore, 1992); Malcolm Cross and Gad Heuman (eds), Labour in the Caribbean; From Emancipation to Independence (London, 1988). 
standard narrative implies. For example, several historians have noted the progressive consolidation of Trinidad's sugar industry after emancipation. According to historian Donald Wood, in 1838 there were 206 sugar plantations in Trinidad. Of these, two-thirds were owned by resident proprietors. In 1866 there were 142 estates in the colony. In 1872 the Colonial Company set up the usine St Madeleine, one of the largest central sugar processing plants in the world, followed by two others, in Northern Plain and in Naparimas, thereby effectively eliminating the production by open-vat methods of inferior Muscovado sugar, and accelerating the expansion of cane cultivation by smallholders on the peripheries of the sugar estates, and the consolidation of industry. In 1896 there were only 52 sugar plantations in Trinidad, and in 1936 that number had dwindled to 32 . By 1959 "the sugar industry was in the hands of five companies". ${ }^{13}$ In other words, after emancipation, the plantation system developed in such a way as to progressively disempower a large group of small-scale producers (a group that might have been expanded to include the freed population), and consolidate the power and prestige of some plantation owners controlled increasingly by metropolitan capital. In addition, historian Kusha Haraksingh has argued that, far from fleeing the sugar estates in revulsion after emancipation, in Trinidad freedpeople were often pushed off, evicted by rationalizing plantation owners eager to eliminate from their workforces those deemed least productive - women, the elderly, children, the infirm and to shift some of the costs of reproducing their labour to the labourers and their families. ${ }^{14}$

Official records indicate that, while Colonial Office personnel eventually accepted claims of labour shortage, and helped develop policies predicated on post-emancipation labour shortage in the British Caribbean, they were not always persuaded by planters' representations of their plight. Rather, constellations of other variables and agendas intersected to make both labour shortage and indentured immigration respectable in the 1840 s. For example, in a letter to Governor Light of British Guiana, Colonial Secretary John Russell rejected allegations that emancipated creoles had become lawless and degenerate after emancipation, as suggested in a petition from British Guiana lobbying for both government-subsidized immigration, and the reopening of India and Africa for labour recruitment. Russell observed:

None of the most inveterate opponents of our recent measures of emancipation allege that the negros have turned robbers, or plunderers, or blood-thirsty

13 Donald Wood, Trinidad in Transition: The Years After Slavery (London, 1986), pp. 36, 295; Bridget Brereton, Race Relations in Colonial Trinidad, 1870-1900 (Cambridge, 1979), p. 49.

${ }_{14}$ Douglas Hall, "Flight from the Estates Reconsidered: The British West Indies, 183842", Journal of Caribbean History, 10 and 11 (1978), pp. 7-24; Kusha Haraksingh, "Control 
insurgents. What appears from their statement is, that they have become shopkeepers, and petty traders, and hucksters, and small freeholders; a blessed change, which providence has enabled us all to accomplish. ${ }^{15}$

Far from sharing petitioners' alarm at this turn of events, Russell argued that they indicated that the Act of Abolition had already gone a long way towards fulfilling Britain's civilizing mission. However, he also noted that the moral victory had come at some cost. "It is important, but still a secondary question," he wrote, "to consider how we can maintain the natural prosperity of our West India colonies, promote the cultivation of products for which the climate is adapted, and keep up, if not increase, the consumption of British manufactures." Russell observed that if these objectives were to be achieved through continued cultivation and export of sugar, then the imperial government ought to help facilitate private colonial efforts to pursue and expand these established economic activities. In short, he proposed that Parliament ought to give "encouragement to a large emigration of labourers into Guiana, Trinidad, and other colonies, with a view to introduce a large population" so that the ratio of land to labour would approximate that of more densely populated Caribbean colonies like Barbardos.

Other research raises questions about the conviction, evident both in primary data and historical interpretations, that women were particularly averse to field labour specifically and wage labour generally. Taken together, the work of Lucille Mathurin, Barry Higman, Hilary Beckles, Marietta Morrissey and other Caribbean historians indicates that since the end of the slave-trade early in the nineteenth century, women had formed increasingly significant proportions of field "gangs" on some plantations in some of the British Caribbean colonies, with no noticeable diminution in the amount of sugar such estates produced. ${ }^{16}$ In $1836-1837$, the Liverpool merchant John Gladstone, along with a few other British Guiana plantation owners in London, had tried to import Indian indentured labourers for his British Guiana estates. In presenting their case to the Colonial Office, Gladstone had professed himself willing to hire as many Indian women for his plantations as men - provided they worked in the fields as enslaved women had done, and for lower wages. ${ }^{17}$

If after emancipation, employers offered freedwomen lower wages than

and Resistance Among Indian Workers: A Study of Labour on the Sugar Plantations of Trinidad, 1875-1917", in Dabydeen and Samaroo, India in the Caribbean, pp. 61-62.

is UK (HC) 1840, XXXIV, no. 121, Russell to Light, 15 February 1840.

${ }^{16}$ Lucille Mathurin, The Rebel Woman in the British West Indies during Slavery (Kingston, Jamaica, 1975); Barry W. Higman, Slave Populations of the British Caribbean 1807-1834 (Baltimore, 1984); Marietta Morrissey, Slave Women in the New World: Gender Stratification in the Caribbean (Lawrence, KS, 1989); Hilary McD. Beckles, Natural Rebels: A Social History of Enslaved Black Women in Barbados (New Brunswick, 1989).

${ }^{17}$ UK (HC) 1838 (232), encl, no. 1, in Gladstone to Glenelg, 22 February 1838; Gladstone to Gillanders, Arbuthnot and Co., 4 January 1836. 
men (as Gladstone had proposed in the case of indentured Indian women) freedwomen may have rejected these conditions, taking up foodcrop cultivation and sales instead - and thus planters may indeed have lost a significant proportion of their pre-emancipation labour force. Whatever its motivations, women's absence from plantation waged labour forces dovetailed with colonial Baptist missionaries' and metropolitan abolitionists' aspirations for emancipation and freed Afro-Caribbean people. In the years before abolition, anti-slavery activists had condemned colonial slavery for what they saw as its perversion of gender roles: specifically, of conjugal and parental rights and responsibilities among slave-owners and enslaved alike. As the journal of the British and Foreign Anti-Slavery Society (BFASS) and other such publications indicates, the veterans of abolitionism hoped to see this situation rectified in bustling postemancipation villages of cottagers, wives and mothers at home, husbands and fathers at work in the fields and workshops. To the extent that abolitionists and their fellow-bourgeois subscribed to a "separate spheres" gender ideology (the Society's refusal to accept the credentials of four American delegates to their World Anti-Slavery Convention in 1840 because they were women suggests that they did so), wage-earning women field labourers jarred with this vision. Most metropolitan reformers of colonial labour conditions did not question, indeed applauded the propriety of freedwomen's declining participation in field labour. Like Russell, they interpreted this as a promising sign of progress among black men and women "degraded" by slavery. ${ }^{18}$

Further, at abolition, British Guiana and Trinidad (along with British Honduras) were distinguished among British colonies in the Caribbean for having more enslaved men than enslaved women: ratios of between 110112 men per 100 women (in British Honduras, the ratio was 162.5:100). ${ }^{19}$ However significant women's removal from plantation labour may have been in other colonies, in these two it may have been less important than contemporaries asserted or assumed. Historian Hilary Beckles has suggested that, "In general, the data suggest that the more developed the colony as a plantation system, the greater the tendency for the normalization of sex ratios, moving from a male predominance under frontier condi-

${ }^{18}$ See, for example, The Anti-Slavery Reporter, published by the British and Foreign Anti-Slavery Society from 1840 on; Howard Temperley, British Antislavery 1833-1870 (Columbia, SC, 1972), pp. 87-90; Clare Midgley, "Anti-Slavery and Feminism in 19thCentury Britain", Gender and History, 5,3 (Autumn 1993), pp. 343-362; Catherine Hall, "Competing Masculinities: Thomas Carlyle, John Stuart Mill and the Case of Governor Eyre", in idem, White, Male and Middle Class. Explorations in Feminism and History (London, 1992), pp. 255-295; idem, "'From Greenland's Icy Mountains [ . . . ] to Afric's Golden Sand': Ethnicity, Race and Nation in Mid-19th-Century England", Gender and History (special issue on Gender, Nationalities, and National Identities), 5, 2 (Summer 1993), pp. 212-230.

19 Higman, Slave Populations, p. 116. 
tions, to female predominance with maturity." ${ }^{20}$ In the "frontier" contexts of Trinidad and British Guiana in the 1830s, where land would have to be cleared and reclaimed, dikes and canals built and dug before cane cultivation could proceed, employers may have preferred male labourers over women, thus giving added incentive to employers and speculators to seek male labourers wherever they could get them, and push women out of the waged plantation workforce.

"Labour shortage" was the idiom in which some British Caribbean sugar planters, along with a coterie of metropolitan creditors and entrepreneurs with investments throughout the British empire represented their unhappiness with conditions under which they both produced and sold sugar. For even as the British Caribbean sugar producers were losing the privileges over labour they had enjoyed under slavery, they were also losing their protected status in the home sugar market. In 1825 Mauritius-grown muscavodo (a low grade of sugar) was admitted into Britain at rates previously reserved for British West Indian sugar. In 1836 the rate was extended to sugar produced in India. By the time of emancipation, it was clear that the abolition of duties that protected British colonial sugar - against even the cheaper and higher quality sugar produced by slave labour in Cuba and Brazil - was imminent.

What the labour shortage argument in fact points to is an attempt to mould sugar production in Trinidad and British Guiana into vertically and horizontally-integrated industries. The motive, for some colonial planters and metropolitan entrepreneurial capitalists, was the relative abundance in the two colonies of still-unexploited land suitable for large-scale sugar cultivation. That this was understood as investment potential was reflected in the fact that higher prices were paid for slaves in these two colonies between 1822 and 1830 than in any other, and established in the significantly higher rates of compensation paid by the British government to slaveowners there, than to those in any other. The average compensation awarded former slave-owners in Honduras, British Guiana and Trinidad was over $£ 50$ per slave. The next highest average compensation was paid to former owners of slaves at the Cape of Good Hope and Mauritius ( $£ 34$ $11 s 7 d$ and $£ 3110 s 6 d$, respectively). In the British Caribbean, those who had owned slaves in the smaller islands of St Vincent, Grenada and St Lucia, received the next highest average compensations: approximately $£ 25-£ 27$, or just over half the average amount awarded former owners of slaves in Trinidad and British Guiana. The average compensation paid for slaves in Barbados, Tobago, Jamaica and Dominica, was between $£ 19$ and $£ 21 .{ }^{21}$

As Eric Williams noted, "Trinidad's economic potential in comparison with that of the exhausted soil of the older islands made the slave in

${ }^{20}$ Beckles, Natural Rebels, pp. 18-19; Higman, Slave Populations, pp. 58-63.

${ }^{21}$ Butler, Economics of Emancipation, Appendix, Table A.1., p. 143. 
Trinidad an infinitely more valuable piece of property than the slave in any other West Indian colony except British Guiana." He added that a labour shortage would result from the intention to expand sugar production. He wrote:

The presence of a mere 17,439 slaves in Trinidad and a mere 69,579 in British Guiana changed the whole course of history of these two colonies after emancipation. The labour problem led to the introduction of an entirely new population in Trinidad, which converted the island from a society of small farmers into a typical plantation economy. ${ }^{22}$ (emphasis added)

The ability of some plantation owners in Trinidad and British Guiana to use their imperial connections to propagate the notion that freedpeople would or did handicap colonial development helped to establish these two as leading British Caribbean sugar producers throughout the nineteenth century. ${ }^{23}$

Not all landowners in the two colonies were as enthusiastic about indentured immigration as those in British Guiana who signed the 1839 petition, or members of the West India Merchants' Association in London. Indentured labour was only affordable on fairly large estates, which could provide the housing and medical facilities required by imperial government and colonial regulations. Historian Bridget Brereton has argued that in Trinidad, French creole planters were displaced as sugar producers by better-capitalized, British-based or -backed owners during the 1840 s and 1870 s as a consequence of reductions in protective sugar duties. Cocoa cultivators in Trinidad (among whom numbered French creoles who had abandoned sugar production to the bettercapitalized British-owned estates, as well as Afro-Trinidadians and, as the century progressed, Indo-Trinidadians) were unenthusiastic about indentured immigration. Free or unindentured workers and smallholders in Trinidad complained that indentured immigration depressed their wages. They, like some historians, pointed out that even during depressions in the sugar industry, Trinidad and British Guiana continued to requisition and get substantial numbers of Indian indentured migrants, who were required to do more work per task than in the past, thereby contributing to deteriorating conditions for all. ${ }^{24}$

Two other factors that contributed to naturalizing labour shortage in Trinidad and British Guiana after emancipation were the imperial government's fluctuating and malleable commitment to free trade, and

22 Eric Williams, Capitalism and Slavery (London, 1987; first pub. 1964), p. 86.

${ }^{23}$ Higman's analysis of data from approximately 1832 modifies Williams's position, but not dramatically: Slave Populations, pp. 102-103.

${ }^{24}$ UK (HC) 1910, XXVII, "Committee on Emigration from India to the Crown Colonies and Protectorates", part 2, Minutes of Evidence; Brereton, Race Relations, pp. 49, 179; Wood, Trinidad in Transition, pp. 107-159; K.O. Laurence, A Question of Labour: Indentured Immigration into Trinidad and British Guiana 1875-1917 (London, 1994), p. 11. 
working-class activism - most notably Chartism - in the 1830 s and 1840 s. The protective sugar duties were attacked as privileges subsidized by high prices paid by British consumers, working-class, middle-class and aristocratic alike. British Caribbean sugar investors successfully argued that the only way for free trade and free labour to triumph in world sugar markets was for British Caribbean sugar producers to import, with imperial assistance, adequate labour from other parts of the British empire. Even some factions within the British and Foreign Anti-Slavery Society came around to the view that indentured immigration into the British Caribbean, specifically from India, was an acceptable price to pay towards the goal of eliminating slavery throughout the world. By 1842, BFASS was torn by conflicting opinions on the sugar duties, elimination of which the central committee in London joined planters and sugar merchants in opposing. In 1844 Thomas Spencer, W.T. Blair and G.W. Anstie sent a circular letter to other BFASS members, urging them to repudiate the resolution in favour of continued protection of British colonial sugars pushed through the 1843 Anti-Slavery Convention by the London Committee. "Who are the men who object to our receiving slave-grown sugar?" they asked. "Not the poor, but a small, very small minority of the more comfortable or richer classes", they responded, adding:

Our own colonies produce enough to supply those who can pay the high price they charge for their sugar, and these, consequently, get enough; but the poor go without, to satisfy the scruples of those who, under any circumstances, know nothing of scarcity. We feel constrained to put it to the latter, whether their conscientious scruples ought to impose sacrifices upon their poorer countrymen, who do not partake of their scruples? 25

It was not coincidental that Indian indentured migration, under the auspices of Parliament, the Colonial and India Offices, colonial and Indian governments, was approved by Act of Parliament in 1844, and the Act providing for elimination of preferential sugar tariffs - as well as that striking down the Corn Laws - was passed in 1846.

The continuing resiliency of the "labour shortage" model of postemancipation labour conditions can in part be traced to its fit with the assumptions, methods and agendas of social history as they developed in the 1960 s and 1970s. If in claiming that they were short of labour nineteenth-century planters represented freedpeople as negatively as they could - as shiftless, lazy, unreliable, heedless, happy-go-lucky and the rest of it - social historians have reread such representations as evidence of freedpeople's resistance to capitalism, planters and their vision of virtue, and as alternative interpretations of the meanings of freedom.

25 "The Sugar Question", The Anti-Slavery Reporter, 5, 7 (3 April 1844), p. 50; Temperley, British Antislavery, pp. 111-136; George J. Schuette, "The London West India Committee, 1838-1854: An Imperial Pressure Group in Action" (Ph.D., Duke University, 1975), p. 85. 
Such rereadings of the primary evidence are not unconvincing. Neither are they unproblematical. They are not only predicated on, but also reproduce assumptions about gender, labour and history that naturalize some aspects of patriarchal authority (the plantation-dominated, sugarproducing, post-emancipation colonial economies, for example) and romanticize others (the idealized bourgeois family), even if they don't necessarily endorse them. With some notable exceptions (Kusha Haraksingh and Rhoda Reddock, for example), the literature on Indian indentured migration to the British Caribbean builds on this scholarship on abolition, emancipation and their aftermath, and for the most part proceeds from the assumption that freedpeople's - and especially freedwomen's - reluctance to continue to work on sugar plantations after 1838 made importation of labour from overseas necessary. ${ }^{26}$ They have not adequately considered either the extent to which ever-emergent imperial discourses on labour, race and gender informed the myriad policies designed and implemented by colonial, imperial and Indian officials for the protection and regulation of Indian indentured migrants; or by extension, the extent to which these large and small acts of empire helped shape the distinctive communities and cultures emergent among Indian migrants and their descendants in the British Caribbean.

Making a colonial labour shortage was a complicated business. It involved mobilization of a battery of discursive resources, as well as transformative interventions in material conditions (colonial legislation and commodification of customary allowances, employer collusion regarding wages and task sizes, strikes by workers). It also involved the emergence of a new, post-emancipation hierarchy of labour imagined in an imperial framework, and based on the presumed cultural affinity and shared history of metropolitan and Caribbean imperial subjects, black and white, and on the absolute alien-ness of other imperial subjects. There was nothing inevitable about Indian indentured migration to the British Caribbean. If Trinidad, British Guiana and to a much lesser extent Jamaica had not been imagined and represented as they were, there would have been no call for Indian indentured immigration. If the price of sugar had not been made such a pressing issue in the early $1840 \mathrm{~s}$, British legislators, bureaucrats, and reformers of domestic and colonial labour conditions might not have been persuaded by the labour shortage thesis. If the shortage had not been cast in terms of freedpeople's racial and social inadequacies, Indian indentured migrants and their descendants might not have been cast the ways they were either. The migration and its representations were scripted in a particular moment of convergences. The rest of the paper turns to consider contemporary discourses on community and culture in colonial India, and how

${ }^{26}$ Hugh Tinker, A New System of Slavery: The Export of Indian Labourers Overseas, 1830-1920 (New York, 1974). 
they were articulated with those on Caribbean labour shortage to produce a historical narrative that further reified the former and naturalized the latter.

\section{Exodus}

Some came with dreams of milk-and-honey riches

fleeing famine and death:

dancing girls,

Rajput soldiers, determined, tall,

escaping penalty of pride.

Stolen wives, afraid and despondent,

crossing black waters,

Brahmin, Chammar, alike,

hearts brimful of hope.

Mahadai Das, "They Came in Ships"

In 1839 , the report on immigration into British Guiana published in the Parliamentary Papers included tables listing the names of each of the Indian indentured migrants brought to the colony by Gladstone and his associates, along with their sex, ages, religions, the estates to which they had been assigned, their occupations on the estates and their wages and allowances. Reports compiled by the Office of the Protector of Emigrants in Calcutta (1871-1910) and Madras listed the emigrants' destinations, the districts in which they were born, those in which they were recruited, their sex, age and caste. In the British Caribbean, to be Indian was to be, first, a sugar worker. This relational identity situated Indians within, often uncomfortably, the history of Caribbean slavery, sugar and British capitalism. Secondarily, to be Indian was to be a migrant, an alien from a space made known and accessible through mediation of British industry and enterprise. In India, to be a labourer invoked other geographic and relational identities, also made known through British industry and enterprise, and sometimes situating labourers within other narratives of bondage. ${ }^{27}$ The difference between these sets of data suggests the parameters in which administrators in British Caribbean colonies and British India operated, the values and identities they assigned migrants, and the categories and conditions to which they attached importance. They also indicate the discursive frameworks - overlapping but not coterminous - which migrants themselves had to negotiate, and in which they had to operate.

Between 1845 and 1917 approximately 450,000 Indian indentured migrants left for the British Caribbean, the majority going (in steeply descending order) to British Guiana, Trinidad and Jamaica. Of these,

${ }^{27}$ Gyan Prakash, Bonded Histories: Genealogies of Labor Servitude in Colonial India (New York, 1990), and "Introduction", in Gyan Prakash (ed.), The World of Rural Labourer in Colonial India (Delhi, 1992). 
the great majority embarked from Calcutta, as British Caribbean employers came to prefer indentured workers recruited in northern India to those recruited in the southern peninsular region and embarked from Madras. After 1862 Trinidad and British Guiana closed their recruiting agencies in Madras, and recruitment for these colonies in the latter region almost ceased. Thanks to a combination of high levels (historically and throughout the indenture period) of seasonal and long-term migration, Indian government policies restricting recruitment by overseas colonial employers to certain areas, and competition from a shifting constellation of recruiters for Assam tea plantations and other industries in the subcontinent, most of those who left for Trinidad and British Guiana from Calcutta were recruited in the following districts in the eastern part of the United Provinces and Bihar: Basti, Azamgarh, Ghazipur, Gonda, Fyzabad, Allahabad, Gorakhpur, Jaunpur, Lucknow, Shahabad; Baraich, Partabgarh, Rae Bareli, Sultanpur, Benares, Bara Banki, Kanpur, and Patna. K.O. Laurence has estimated that of the nearly 271,900 recruit registrations recorded in the Calcutta emigration department records, nearly 198,000 were registered in the first ten districts above, and nearly 56,500 in Kanpur, Benares and Patna ${ }^{28}$ Further, the majority of those registered were born in the same districts, although there was also considerable registration of recruits born in Bengal, the Central Provinces, and elsewhere in India. Indentured migrants to the British Caribbean appear to have been drawn from a representative cross-section of these regions' populations, various castes being represented in the migration in proportions commensurate with those of the recruiting regions in general. Families appear not to have emigrated together.

In 1838 the Master Pilot at Calcutta testified that, to his mind, the migrants who boarded the British Guiana-bound Whitby, "were generally composed of ignorant creatures from the interior, kidnapped or cajoled away for the benefit of a set of crimps who laugh at humanity for the sake of profit". ${ }^{29}$ Some twenty years later, Jane Swinton, widow of the captain of the Salsette, which had transported migrants to Trinidad wrote, "out of the 324 Coolies who came on board, I do not believe five, at most, either know where they are going, or what is to be their occupation". She added, "My heart often yearned over them, in thinking of the way they were entrapped, as many of them asked me to recommend them to get a good situation on their arrival at the island." 30 Of the 324 passengers ( 274 of whom were adults) who left the Hooghly aboard

${ }^{28}$ Laurence, A Question of Labour, pp. 107-108.

${ }^{29}$ Bengal Government, "Coolie Export Enquiry 1838-1840", Appendix no. 4; reprinted in UK (HC) 1841, XVI, nos 287 and 483.

${ }^{30}$ Captain and Mrs Swinton, Journal of a Voyage with Coolie Emigrants, from Calcutta to Trinidad (London, 1859), p. 12. 
the Salsette on 17 March 1858,120 or more than one-third, died en route.

These two eyewitness reports fit with and illustrate that strand of the literature, contemporary and historical, that in language reminiscent of abolitionist accounts of the African slave-trade, has cast indentured migrants as victims of unscrupulous merchants and their procurers. It was accounts such as these that in 1840 disposed Colonial Secretary Russell against allowing resumption of Indian indentured migration to Mauritius and British Guiana, the lobbying of their sugar industries notwithstanding, on the grounds that it might "lead to a dreadful loss of life on the one hand, or, on the other, to a new system of slavery." 31 In 1839 three of six commissioners appointed by the Government of Bengal to investigate charges of abuse against that recently-suspended migration concluded that "the Coolies and other Natives exported to Mauritius and elsewhere, were (generally speaking) induced to come to Calcutta by gross misrepresentation and deceit practised upon them by native crimps styled Duffadars and Arkotties employed by European and Anglo-Indian Undertakers and Shippers who were mostly cognizant of these frauds, and who received a very considerable sum per head for each Coolie exported". They strongly advised against resumption of the migration, noting that "permission to renew this traffic would weaken the moral influence of the British Government throughout the world, and deaden or utterly destroy the effect of all future remonstrances and negociations [sic] respecting the slave trade". ${ }^{32}$ Subsequently, other critics of the system, contemporaries and historians alike, have elaborated on this theme, arguing that indentured emigrants were victims of simple deception or, more broadly, of British revenue settlement and land tenure policies of the nineteenth century, and backing their argument with evidence from ethnographic surveys and other such enterprises of colonial rule in India.

Another strand in the literature, however, argues that whatever the reasons for their immiserated condition, indentured emigration represented a "Great Escape" for enterprising Indians, an opportunity to turn colonial subordination at home to their own advantage abroad - and that women, in particular, may have seized it as such. ${ }^{33}$ Two others

${ }^{31}$ UK (HC) 1840, XXXIV, no. 121, Russell to Light, 15 February 1840.

32 Bengal Government, "Coolie Export Committee", Majority Report (Chairman Theodore Dickens, Rev. James Charles, Russomoy Dutt), p. 2.

33 P.C. Emmer, "The Great Escape: The Migration of Female Indentured Servants from British India to Surinam, 1873-1916", in David Richardson (ed.), Abolition and its Aftermath: The Historical Context, 1790-1916 (London, 1985); Rhoda Reddock, "Freedom Denied: Indian Women and Indentureship in Trinidad and Tobago, 1845-1917", Economic and Political Weekly, 20-43 (26 October 1985), pp. 79-87; Pat Mohammed, "Writing Gender into History: The Negotiation of Gender Relations among Indian Men and Women in Post-Indenture Trinidad Society, 1917-1947", in V. Shepherd, B. Brereton and B. 
appointed to the 1839 enquiry by the Government of Bengal disagreed with the findings of their three colleagues, and submitted dissenting reports of their own. J.P. Grant, who was later to be appointed Protector of Emigrants at Calcutta worried that "To confine the laborers of a Province to the soil of that Province, or the laborers of a collection of Provinces, such as our Indian Empire consists of, to the soil of the same, seems to me, but a lower degree of the barbarous system which attaches a serf to the lord on whose soil he was born, or imposes special restrictions on the movements of free coloured native subjects." Warning that "The prosperity or existence of whole Colonies, and the liberty of tens of millions of British subjects, are not light matters," Grant concluded that "If the recommendation of the [majority] Report is adopted, we have opinions before us that Mauritius must be ruined; and it is unquestionable that the mass of our Indian fellow subjects are no longer free men as before." $34 \mathrm{He}$ proposed that the emigration be allowed, but under government supervision to minimize the risks of fraud, deception and kidnapping that he admitted had marred the migration under investigation (1834-1838). Elaborating on Grant's analytical framework, subsequent investigators, supporters and some historians have argued that Indian indentured emigrants had made the rational choice to take advantage of their imperial subject-hood and that, minor and removable obstacles aside, had been able to maximize opportunities to an extent that in India, paralysed by tyrannies of caste and tradition, would have been impossible. ${ }^{35}$

Represented both as victims and as rational, indeed wily, maximizers of opportunity throughout the history of indentured emigration, Indian indentured emigrants probably included fair shares of both. Complicating the picture is evidence that awareness of conditions in overseas colonies grew, not only because recruitment appears to have been concentrated in certain areas, but also because migrants were returning to India, either to settle or to visit - and sometimes to act as recruiters themselves. ${ }^{36}$ Recent research indicates that multiple trips between India and the Caribbean by people who had made the initial voyage under indentures were not uncommon. In 1851, the first year Indians were eligible for repatriation, twelve of those who took the opportunity to return to India came back to British Guiana within the year. Based primarily in

Bailey (eds), Engendering History: Caribbean Women in Historical Perspective (New York, 1995), pp. $20-47$.

${ }^{34}$ Bengal Government, "Coolie Export Committee", in James P. Grant, Minute Dissenting from Majority Report.

${ }^{35}$ J. Geoghegan, Note on Emigration from India (Calcutta, 1873); D.W.D. Comins, Note on Emigration from the East Indies to Trinidad (Calcutta, 1893); UK (HC) 1910, XXVII, 1, pp. 17, 58-59; Emmer, "Great Escape".

${ }^{36}$ Marina Carter, Servants, Sirdars and Settlers: Indians in Mauritius, 1834-1874 (Delhi, 1995). 
colonial immigration and Indian Emigration Department annual reports and other documents, K.O. Laurence's research suggests that between 1875 and $1894,3,479$ Indians re-migrated to British Guiana, with another 2,347 migrating there after having served out indentures in another colony. Over the same period, 866 Indians re-migrated to Trinidad, with another 1,753 migrating there after having served in another colony. In 1893, 306 Indians returned under indentures to British Guiana, along with 253 who had been indentured in other colonies. ${ }^{37}$ Conditions in India, specifically in the areas of primary recruiting for British Guiana and Trinidad, were not unchanging or unchanged by this migration.

In 1883 George A. Grierson was assigned to inspect and report on the condition of recruitment depots throughout Bengal Presidency. His report and diary suggest that returned migrants were common in some districts from which others were recruited. In Shahabad, for example, in which district a relatively high proportion of recruits were registered (and one of the few districts in which the bulk of those registered also resided), Grierson claimed that there had been "a healthy inflow of returned emigrants, which has made emigration so popular as it is". ${ }^{38}$ He felt that returned emigrants could make admirable recruiters, if they had been successful in the colonies, and puzzled over colonial employers' failure to capitalize on this resource, so effectively exploited by Assam tea estates. ${ }^{39} \mathrm{He}$ did, however, encounter one recruiter who had been in an importing colony, although not necessarily as an indentured migrant himself. Ghura Khan, who ran a sub-depot near Baksar, had been born in British Guiana, and returned to India with his mother in 1858 to live with his uncle, after his father's death. He re-emigrated to the colony with seven other family members in 1861 . On his mother's death in 1872 , he returned to India, and had been about to re-emigrate again when the agent for British Guiana persuaded him to stay on as a recruiter.

In the course of his inspection tour, Grierson met a number of returned emigrants, and recorded what he remembered of his conversations with them in his diary. For the most part, those he met and reported on (they had gone to Mauritius, Jamaica or British Guiana) had managed to save money overseas. Some had corresponded with their families and sent remittances home, and these had all been received. Indeed, he wrote, "In every village to which I went, three or four letters, which were shown to me, had been received, during the past year or two, from one colony or another. To all these, I was told, answers had been despatched." ${ }^{40}$ Grierson added that ensuring ready means of communica-

${ }^{37}$ Laurence, $A$ Question of Labour, pp. 127-128.

${ }^{38}$ George A. Grierson, Report on Colonial Emigration from the Bengal Presidency (Calcutta, 1883) [hereafter Colonial Emigration], p. 42.

${ }^{39}$ Grierson, Colonial Emigration, pp, 42, 34; Carter, Servants, Sirdars and Settlers.

${ }^{40}$ Grierson, Colonial Emigration, Diary, 8 January 1858. 
tion between emigrants and those they left behind would facilitiate recruitment and improve the standing of indentured emigration in districts where, unlike Shahabad, it was not already good.

Some of the returned emigrants Grierson met had spent all their money, and were re-indenturing. Others, like Gobardhan Pathak, Nankhu, Tulsi Bhagat, Sukhiya and Ghura Khan had invested it in land or shops on their return, and in "getting back into caste", to which end they had apparently spent between Rs. 100 and Rs. 300. Thanks to such cases, Grierson concluded, in districts like Shahabad and Patna,

with regard to colonial emigration, the main facts are clearly and universally understood; namely, that a coolie goes out for five years; that if he stays for ten he gets a free passage home; that he is well treated, his caste respected, and comes home rich. The climate of the colonies is delightful, work plentiful and highly paid; and that stories, circulated some years ago, about mimiai ka tel (the oil extracted from a coolie's head by hanging him upside down), are all lies. When people are asked how they know all this, the reply always is that so-and-so went off to the Colonies so many years ago, came back, abused Hindustan and praised the colony and went out again, this time with his wife and children. ${ }^{41}$

Grierson reported that "In Shahabad, where emigration is popular, the recruiters have little trouble. Twelve-sixteenths of the recruits search for the recruiters, and voluntarily emigrate. I have known instances of men coming forty miles to look for a sub-depot." However, he continued, "In other districts it is just the reverse. There, there are few returned emigrants, and little is known about the colonies", and recruiters had to beware of zamindars, anxious not to lose their people, as well as a hostile constabulary. ${ }^{42}$ While Grierson may not have heard, or chose not to record, unfavourable accounts of indentured emigration from returned emigrants or from emigrants' relatives, such information was probably circulating in districts like Shahabad and Patna, along with the rest, and had an equally immeasurable impact on recruitment and migrants' adjustment to life as plantation labourers overseas.

Laurence's research and Grierson's notes suggest that by the 1880 s, repeat migrants were likely to number among those sent out on each ship leaving Calcutta for the British Caribbean colonies. A Colonial Office publication of the same period suggests what this meant to some contemporaries. In 1889 J.M. Laing, a veteran surgeon-superintendent aboard ships transporting Indian indentured migrants to the British Caribbean, wrote for the edification of unseasoned colleagues a handbook on maintaining discipline and health aboard ships transporting indentured emigrants from India. When problems arose, as they inevitably would, he advised, "look out for some return coolie as the instigator.

${ }^{41}$ Grierson, Colonial Emigration, p. 18.

${ }_{42}$ Ibid., p. 15. 
They will often give themselves airs among the other coolies, who will naturally believe that they know all about it from having been on previous voyages, and they are generally too knowing or too great cowards to complain themselves, but put some other coolie up to doing so." He continued:

Sometimes Brahmins and other high caste Hindoos will come up and say that they cannot eat food prepared in the galley, and this, although they have been told before embarking that their food would be thus prepared. Often this man's prejudice (his caste has been broken by the mere fact of his having lived in the depot even up country) can be satisfied by putting him into the galley as a bandharrie, if the complaint has not been made for that purpose and there is a vacancy.

He added, in a footnote: "N.B.: There are a good many pseudobrahmans about." ${ }^{\prime 43}$

Like surgeon-superintendent Laing, employers in the colonies were not always pleased about re-indenturing immigrants from India. ${ }^{44}$ During the mid-1880s, sugar prices throughout the world fell as a result of sugar from bounty-fed European sugar beet production, and market wages in Trinidad and British Guiana dropped by as much as a third, to below the minimum stipulated for indentured labourers. Some estates employing indentured labour tried, illegally, to depress indentured workers' wages, or to increase the size of the tasks assigned them, which effected the same ends. Indentured workers who refused or failed to meet the new conditions imposed on them were brought in large numbers before the courts for punishment: fines or imprisonment. In the 1880 s planters' complaints against indentured workers for such transgressions escalated, some employers attributing the unrest to re-indentured veterans among the indentured labourers. ${ }^{45}$

Employers in the British Caribbean shared Laing's suspicions not only of re-indentured returned immigrants, but also of high-caste, specifically Brahmin, immigrants. In 1889 the Government Secretary for British Guiana complained to the Calcutta agent, Robert Mitchell, that:

the introduction of priests, high castes, coolies, members of the learned professions, decayed gentry, beggars, dancers, acrobats, vagrant musicians, men of inferior physique or health, persons not previously accustomed to outdoor

${ }^{43}$ James M. Laing, Handbook for Surgeons Superintendents of the Coolie Emigration Service, CO/PRO 885/9 Miscellaneous, no. 75 (Colonial Office, 1889), pp. 41-42.

44 UK (HC) 1910, XXVI, no. 2, "Emigration from India to the Crown Colonies and Protectorates", Minutes of Evidence, Warner, pp. 29-30; Tyran Ramnarine, "Over a Hundred Years of East Indian Disturbances on the Sugar Estates of Guyana, 18691978: An Historical Overview" [hereafter "East Indian Disturbances"], in Dabydeen and Samaroo, India in the Caribbean, p. 25; Laurence, A Question of Labour, p. 128.

${ }^{45}$ Ramnarine, "East Indian Disturbances", pp. 122, 125; Laurence, A Question of Labour, pp. $116,132,149$. 
manual, much less field labour, has been more numerous during the past five years or so.

In 1890 the Planters' Association of British Guiana passed a resolution instructing their Emigration Agent in Calcutta to prevent such recruits from indenturing themselves for terms in their colony. Mitchell, for his part, tried to persuade his employers that caste was not a very good indicator of migrants' ability or willingness to perform the kind of labour they required, and in 1896 the Colonial Office rejected British Caribbean employers' attempts to attribute the low wages actually earned by Indian indentured workers on their plantations to the workers' unsuitability and poor selection by agents in Calcutta. ${ }^{46}$ Nevertheless, managers in the British Caribbean continued to suspect that pre-migration associations and hierarchical values shared by all migrants from India could undermine their own authority as employers or supervisors on the plantations. There is evidence that they tried either to break these "traditional" ties of deference and loyalty, or turn them to their own advantage. ${ }^{47}$

Implicit in all of this is an essentialist assumption about the culture and societies that migrants (whether enslaved, indentured or "free") left behind, and a static conception of culture. ${ }^{48}$ One indication that the communities from which indentured emigrants were recruited were not unchanging or unchanged by decades of recruitment for indentured emigration is the emergence of emigration-specific cultural strategies, such as that described by Grierson in 1883 . He noted that, "About caste, the people have invented a curious theory regarding ship-board life, which shows the adaptability of native customs." Asked how people from castes (Sonars, for example) whose members would not eat food cooked by Brahmins managed on board ships where most of the cooking was done by Brahmins, Grierson was told that "a man can eat anything on board-ship. A ship is like the temple of Jagannath, where there are not caste restrictions". He added:

I admit that this rather staggered me, but I have since enquired from respectable men, and without doubt this belief is spreading. It is said to have originated with the steamer journey from Calcutta to Orissa, which is one of the incidents of a pilgrimage to Jagannath. On board these ships the theory was first introduced, as one of the incidents of the pilgrimage, and is now being extended to emigrant ships, to the great benefit of the Colonies. ${ }^{49}$

Together with the rest of Grierson's report, this story suggests a number of things. One: that contemporary and scholarly assessments notwith-

46 Ibid., pp. 115-118.

${ }^{47}$ Ramnarine, "East Indian Disturbances", p. 125; Haraksingh, "Control and Resistance", p. 67.

${ }^{48}$ Peter van der Veer, "The Idea of Diaspora: South Asians Overseas", in Peter van der Veer (ed.), Nation and Migration: The Politics of Space in the South Asian Diaspora (Philadelphia, 1995), p. 4.

49 Grierson, Colonial Emigration, Diary, 8 January 1883. 
standing, caste was not a good predictor of people's willingness to emigrate under indenture. Two: that at least in the Bhojpuri-speaking region of India, rural populations were by no means stationary, and cultural forms and practices by no means unchanging. People were on the move, performing pilgrimages, looking for employment on both seasonal and longer terms, migrating to and from agricultural regions, towns and cities. Three: that familiarity with conditions in overseas colonies was increasing in some recruitment areas. However, the areas in which concentrated recruitment for indentured migration took place changed over time, along with local factors ranging from competition over labour with recruiters for tea estates in Assam and coal mines in Chota Nagpur and elsewhere, as well as railway construction further afield. ${ }^{50}$ By the twentieth century, recruiters were going as far afield as Delhi to fill colonial demand for indentured labour, and meeting with the kinds of hostility Grierson observed in parts of Bengal Presidency in $1883 .{ }^{51}$ Even if people in some regions were increasingly aware of what indenturing involved, those in or from other regions were not necessarily so situated. In other words, there was not necessarily a steady improvement over time in migrants' preparedness for indentured migration. However glorified Grierson's image of the colonies and plantation labour, his report and diary suggest that by 1883 conditions of indentured emigraton were not entirely unknown in the districts from which most emigrants were recruited. All these myriad factors had implications for the ways employers of Indian indentured migrants treated them, and for their affiliations and institution-building both on and off the plantations.

Historians have sought to decode data on caste and regional origins as if they will explain present-day Caribbean-Indian communities and cultures. Regarding Indian women, migrants and settlers alike, the tendency is especially pronounced, and casts into stark relief the problems with the entire enterprise. Statistical data compiled from emigration and immigration records suggest that the majority of migrating women were not accompanying male relatives. Other documentary evidence suggests that colonial officials, plantation personnel and other observers in India, on the migration ships and in the importing colonies viewed alliances between indentured men and women with considerable scepticism, characterizing them as illegitimate unions springing from depot and ship conditions and Indians' lust and immorality, indicative of migrants'

50 Dirk Kolff, "Indian Expansion and Indian Diaspora: The Original Context of Emigration", unpublished paper, ISER-NCIC Conference on Challenge and Change: The Indian Diaspora in its Historical and Contemporary Contexts, University of the West Indies, St Augustine, Trinidad, 13 August 1995; Ian J. Kerr, Building the Railways of the Raj 18501900 (Delhi, 1995).

51 UK (HC) 1910, "Emigration from India to the Crown Colonies and Protectorates", Report, pp. 17-18. 
degraded condition and corrupting influence. ${ }^{52}$ Some recruiting agents in India complained bitterly that Indian magistrates interfered with the registration of women and the embarkation of emigrant ships because they were convinced that the women were either being coerced into indentured emigration, or fleeing the authority of fathers or husbands. Opponents of indentured emigration charged that recruits were being "scripted", told by "up-country" recruiters how to respond not only to magistrates', doctors', and Protectors' questions, but also to those that colonial emigration agents might ask. Grierson's field notes suggest that records on recruits were poorly maintained, sometimes clearly fraudulent and intended to meet requirements rather than to record recruits' vital statistics. ${ }^{53}$ None the less, many historians, like most contemporary observers, have concluded that migrating women were either hapless victims kidnapped, seduced, or possibly widows escaping unbearable conditions at home - or (already) prostitutes, fallen women, the "sweepings of the bazaars" and lock hospitals.

Others have evaded such characterization, instead focusing on exploring some of the implications of the unequal sex ratio that, for the duration of indentured periods, characterized this migration predicated on the assumption that men made better plantation labourers than women. Rhoda Reddock and Patricia Mohammed have suggested that under these conditions Indian women were vulnerable to exploitation by sex-starved men (Indian, white, or Afro-Caribbean) on colonial plantations, and to patriarchally-minded Indian men in Indian villages off them. They also suggest that in the context of Indians' isolation on and near plantations where they came to represent an increasingly large proportion of the labour force, Indian women's scarcity could give them more control over their own labour and sexuality than they could hope to have in less anomalous circumstances. They argue that in colonial Trinidad, Indian labour and culture appeared devalued and emasculated by indenturing and isolation on plantations, juridical marginalization and colonial policy. For example, like many contemporaries, they point out that colonial law recognized only those marriages between Indians that were performed by a Christian clergyman or registered by an authorized civil servant such as the Protector of Immigrants. According to Reddock, no marriages were registered until 1887 , and even after that few unions between Indian men and women conformed to these legal standards, thus contributing to the perception that Indian immigrants were amoral and promiscuous. Marriages performed by Muslim and Hindu clergy were not recognized by law until 1936 and 1945 respectively, but Indians

52 Swinton and Swinton, Journal of a Voyage; Comins, Note on Emigration; "Emigration from India to the Crown Colonies and Protectorates", Report, Minutes of Evidence, Appendices.

53 Grierson, Colonial Emigration, p. 69; UK (HC) 1910, 2, "Emigration from India, etc.", Minutes of Evidence, Bolton, p. 191. 
campaigned for recognition from the last quarter of the nineteenth century. Reddock and Mohammed argue that in campaigning to get those marriages performed according to Muslim and Hindu custom and laws recognized by the colonial state, Indian men were reclaiming the patriarchal authority they had lost in the course of emigration and indentured labour on sugar plantations. ${ }^{54}$

Reddock argues persuasively that culture and community formation must be seen as discursively constituted by struggles among not only immigrant and creole-Indian men and women, but also between them and other segments of Trinidad's population. However, in so far as these studies assume for Indian women indentured migrants the pre-migration condition of domestic-patriarchal and rural-agrarian bondage, they reproduce and reinforce assumptions about the static quality of Indian culture and Indian people introduced and elaborated since the mid-nineteenth century. By extension, they then also contribute to making Indian indentured migration overseas seem anomalous in, separate from, and only marginally significant to Indian labour history specifically, and to the contours of Indian colonial history more generally.

Implicit in the "new system of slavery" narratives is the assumption that traditionally, in other words before British intervention, people in the recruiting regions were largely stationary, and that indentured emigration was just another facet of the ongoing displacement and immiseration precipitated by colonialism. Uprooted, these migrants to overseas colonies like Trinidad and British Guiana struggled to reproduce remembered village communities to the best of their abilities, the unpromising ground of local plantation conditions permitting. ${ }^{55}$ Implicit in the Whiggish "great escape" account of emigrants' motivations is the functionalist and modernization notion that, freed from the heavy hand of custom, these Indian indentured migrants transplanted in their new worlds those cultural forms and features they valued, rejecting oppressive features of Indian society.

Neither alternative seems satisfactory on its own. While a continuous history of massive deception seems implausible, there is also evidence that cases of abduction and entrapment continued throughout the seventy years. ${ }^{56}$ Further, people in the recruiting districts were not unaffected by land and revenue settlements, industrial and agricultural developments,

${ }^{54}$ Reddock, "Freedom Denied"; Mohammed, "Writing Gender into History".

ss Chandra Jayawardena, "Ideology and Conflict in Lower Class Communities", Comparative Studies in Society and History, 10 (July 1968), pp. 412-446; Ramnarine, "East Indian Disturbances"; Haraksingh, "Control and Resistance", Brinsley Samaroo, "The Indian Connection: The Influence of Indian Thought and Ideas on East Indians in the Caribbean", in Dabydeen and Samaroo, India in the Caribbean, pp. 43-60.

${ }_{56}$ Haraksingh, "Control and Resistance", and "Structure, Process and Indian Culture in Trinidad", in Howard Johnson (ed.), After the Crossing: Immigrants and Minorities in Caribbean Creole Society (London, 1988), pp. 117-119. 
railway construction and other effects and technologies of colonial rule..$^{57}$ All of this may have had implications for community-formation among Indian indentured migrants and their descendents in the British Caribbean and elsewhere, although those predicated on push and pull models of motivation for emigration are unsatisfying, in part because such causation models seem clumsy. It is problematical to trace present-day cultural values and practices of Indo-Caribbeans back to origins in pre-migration India when the migration took place over an extended period, and when the bulk of migrants appear not to have travelled as families or village groups. More compelling is the suggestion that crucial institutional and political developments took place dialogically in the period between the $1880 \mathrm{~s}$ and 1947. This period saw the founding of the Indian National Congress (1885) and related oppositional movements, and missionary activity by both Arya Samaj and Sanatan Dharm among overseas Indian communities. Indeed, the significance of communities of Indians overseas for the emergence of Indian nationalism and its strategies in the subcontinent, as well as the significance of these for crystallization of Indian identities in overseas British (and other European) colonies is relatively unexplored, although suggestive. ${ }^{58}$

\section{Conclusion}

I alone am today alive.

I remember logies, barrackrooms, ranges,

nigga-yards. My grandmother worked in the field.

Honourable mention.

Creole gang, child labour.

Second prize.

I recall Lallabhagie, Leonora's strong children,

and Enmore, bitter, determined. ${ }^{59}$

Mahadai Das, "They Came in Ships"

57 Bernard S. Cohn, An Anthropologist among the Historians and Other Essays (Delhi, 1990); Gyan Prakash, "Writing Post-Orientalist Histories of the Third World: Perspectives from Indian Historiography", Comparative Studies in Society and History, 32 (April 1990), pp. 383-408; Nicholas B. Dirks, "Castes of Mind", Comparative Studies in Society and History, 37 (Winter 1992), pp. 56-78.

ss Prabhu Mohapatra, "Longing and Belonging: Dilemma of Return among Indian Immigrants in the West Indies 1880-1940", paper presented at the ISER-NCIC Conference on Challenge and Change: The Indian Diaspora in its Historical and Contemporary Contexts, University of the West Indies, St Augustine, Trinidad and Tobago, 14 August 1995; John D. Kelly, A Politics of Virtue: Hinduism, Sexuality, and Countercolonial Discourse in Fiji (Chicago, 1992); Samaroo, "The Indian Connection"; Peter van der Veer and Steven Vertovec, "Brahmanism Abroad: On Caribbean Hinduism as an Ethnic Religion", Ethnology, 1 (1991), pp. 149-166; Steven Vertovec, Hindu Trinidad: Religion, Ethnicity and Socio-Economic Change (London, 1992).

59 Leonora and Enmore were plantations in British Guiana that had employed large numbers of Indian workers, indentured and unindentured, and which were the sites of frequent, sometimes bloody "disturbances and strikes" between 1870 and 1905: Walter 
Popular and scholarly concern with origins implicitly denies agency to migrants and their descendants and, more generally, to people in history. It overshadows the processes and struggles whereby people living in Trinidad from 1845-1917 constituted themselves at various times and in various places along the multiple and sometimes overlapping axes of sex, age, marital status, "race" or ethnicity, conditions of migration and time of arrival, relation to the means of production, sexual orientation, and so on. This article has suggested that, while the documentary evidence on migrants' backgrounds and origins are voluminous, they are also unevenly reliable, and problematically presume unchanging material and discursive conditions in Indian recruitment zones over a period of more than seventy years. The very processes, ongoing, of recruitment and immigration challenge notions of stasis in both sending and receiving regions' economies, social relations and cultures. Further, these regions were not autonomous, but, rather, linked with and through colonial and imperial alliances, rivalries and discourses that were themselves fluid, unstable, emergent.

Knowledge, however imperfect, of conditions on the other side of the world was accumulated and disseminated not only in the migrations and memories of repatriating and repeat-emigrants from India to the British Caribbean colonies, but also in the form of data like Grierson's report and other writings: scholarly, popular and administrative reports, censuses, surveys, maps and digests of all of these, as well as in the circulating personnel of imperial administration, from soldiers to governors. The implications of all this information for the ways Indians were legislated on, administered, punished and rewarded and, by extension, for the ways in which they responded to and negotiated these efforts are provocative, although as yet little explored. If migrants' communities and cultures took on what appear to be distinctively Indian forms, the extent to which such forms were privileged by employers and by government administrators - as well as by other people and interests in both India and the Caribbean colonies needs to be considered. After all, Indians' perceived difference from Afro- and Euro-Caribbean people was one of the reasons for their being in the Caribbean in the first place. What this difference meant, and the ways it was staged and performed itself differed and changed along with the circumstances, resources and agendas of the women and men who invoked or rejected it. 